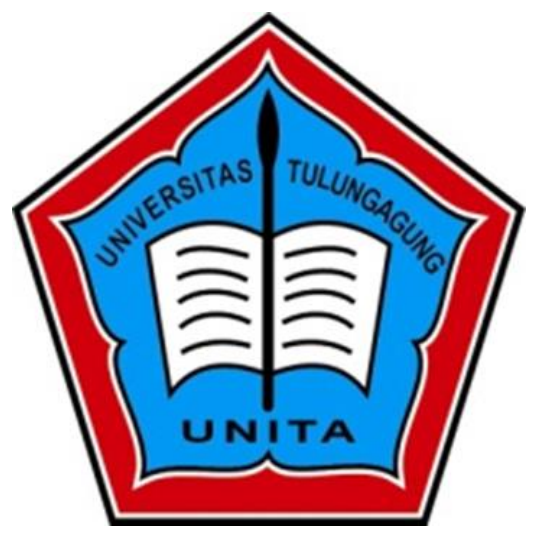

RATIH RACHMA KURNIA

17.60301.1.00015

ERMA PURWATI

17.60301.1.00020

FAKULTAS EKONOMI

UNIVERSITAS TULUNGAGUNG

2021 


\author{
ANALISIS MANAJEMEN PEMASARAN \\ KPOP ONLINE SHOP “K-SHIRT TG” (@kshirttg_)
}

\begin{abstract}
Abstrak
Riset ini berisi tentang “Analisis Manajemen Pemasaran Kpop Online Shop KSHIRT TG (@kshirttg_). Riset ini bertunjuan untuk mengetahui bagaimana manajemen pemasaran yang dilakukan oleh owner UMKM ini agar dapat terus berkembang dan bertahan disegala permasalahan yang timbul. Penelitian dilakukan 15 Oktober 2020 s.d 31 Oktober 2020 di Desa Karanganom, Kec. Durenan, Kab. Trenggalek dengan melibatkan owner secara langsung, dapat dijelaskan bahwa pemasaran online sangat efektif dan efisien dengan produk yang menarik dan kepercayaan konsumen yang dibangun,
\end{abstract}

Kata Kunci : Manajemen Pemasaran, Kepercayaan Konsumen

\title{
Pendahuluan
}

Pemasaran produk merupakan salah satu kunci untuk seorang wirausaha dapat memaksimalkan tujuan usahanya untuk dapat menghasilkan laba. Pemasaran produk ini sangat penting agar usaha dapat tetap dijalankan dan terus berkembang. Ada banyak metode pemasaran yang dapat dipilih untuk memasarkan produk, dari system tradisional yang mana dilakukan dengan promosi mulut ke mulut sampai ke pemasaran di sosial media mengingat perkembangan teknologi sangat mendukung dan membantu bagi wirausaha dapat selalu mempromosikan produknya.

Penerapan strategi pemasaran yang bagus dapat menarik perhatian public yang akhirnya menambah banyak customer baru. Variasi dan inovasi juga harus dikembangkan agar produk tidak monoton bisa mempertahankan customer lama tetap membeli produk-produk yang dipasarkan.

Penerapan aplikasi e-commerce sebagai fungsi dari pemasaran, penjualan dan pelayaran yang bertunjuan untuk meningkatkan kepuasan pelanggan, terutama untuk mendapatkan, mempertahankan dan meningkatkan jumlah pelanggan.

Saat ini, pelaku usaha sangat dimudahkan dengan adanya sosial media yang dapat diakses banyak orang secara bersama-sama dan dalam waktu singkat, ditambah lagi 
berkembangnya aplikasi jual beli seperti Shopee, Lazada, Tokopedia, dll semakin memperluas pasar ke kancah nasional bahkan internasional.

KSHIRT TG adalah salah satu UMKM yang bergerak di bidang industry tekstil, sablon, dan percetakan dengan alamat di Jalan R.A Kartini, Dusun Dempok RT. 016 RW. 003 Desa Karanganom, Kecamatan Durenan, Kabupaten Trenggalek, JAWA TIMUR. Sistem penjualan yang digunakan dari awal pembukaan usaha tahun 2019 adalah online. Penjualan telah mencapai kancah nasional dalam beberapa bulan seperti pengiriman ke Jambi, Jakarta, NTT dll merupakan pencapaian bagus untuk usaha online tersebut. Permasalahan yang timbul adalah dimana jika suatu produk yang dipasarkan secara online tidak mendapatkan citra di lingkungan sekitar. Hal ini dikarenakan tidak adanya bangunan toko yang tampak nyata untuk usaha ini. Dari permasalahan tersebut perlu adanya pemasaran secara tradisional dan penataan toko offline walaupun pemasaran tetap dilakukan secara online karena penataan toko nyata akan menambah kepercayaan publik.

\section{Landasan Teori}

\section{Menejemen Pemasaran}

Pengertian manajemen pemasaran adalah alat analisis, perencanaan, pelaksanaan dan pengendalian proses, yang bertujuan untuk membuat, menetapkan dan memelihara transaksi yang menguntungkan dengan sasaran pasar untuk mencapai sasaran laba utama perusahaan. Menejemen pemasaran menurut para ahli adalah :

a. Menurut Kotler, 1980. Manajemen pemasaran adalah analisis pasar, perencanaan, pelaksanaan dan pengawasan rencana pada sasaran pasar, yang bertujuan untuk berkomunikasi dengan pasar sasaran untuk mencapai tujuan perusahaan. Sehingga target dan tujuan sasaran pasar bisa berjalan dengan lancar. ${ }^{1}$

b. American Marketing Association, Adapun penjabaran dari definisi pemasaran adalah sebagai berikut: Pemasaran merupakan suatu cara pelaksanaan dalam dunia bisnis yang mengalirkan barang dan jasa dari produsen ke konsumen, pembeli atau pengguna. Definisi yang telah

\footnotetext{
${ }^{1}$ Philip Kotler, 'Marketing Management: Analysis Planning Implementation and Control', Journal of Retailing, 88(3) (1994).
} 
dipaparkan ini hanya menekankan pada aspek distribusi penjualan, bukan kegiatan pemasaran. ${ }^{2}$

c. Philip Kotler (Philip Kotler) dalam karyanya "Marketing Management Analysis, Planning and Control" definisi yang lebih luas dari pemasaran, yaitu: pemasaran adalah: proses sosial, individu dan kelompok untuk mendapatkan barang maupun jasa atau apa saja yang mereka butuhkan, Dan dapatkan. Apa yang mereka inginkan dengan bekerja sama dengan individu lain untuk menciptakan dan memelihara produk atau barang dan nilai. Dan kelompok lainnya. ${ }^{3}$

2. Tujuan Manajemen Pemasaran

a. Menciptakan Permintaan

Tujuan utama dari manajemen pemasaran adalah membuat pelanggan membuat permintaan dengan berbagai cara untuk memenuhi kebutuhan. Membuat metode yang terencana dan mengetahui preferensi atau kebutuhan dan selera konsumen akan barang atau jasa yang memenuhi kebutuhan pelanggan sehingga pelanggan tertarik untuk membeli barang di perusahaan tersebut.

b. Kepuasan Pelanggan

Penyediaan barang atau jasa yang dibutuhkan oleh pelanggan harus benar-benar dipahami dalam kegiatan pemasaran produk. Pemasaran modern berorientasi pada pelanggan maka kepuasan pelanggan merupakan hal yang penting.

c. Pangsa Pasar atau Market Share

Meningkatkan pangsa pasar dimaksudkan untuk menambah rasio penjualnnya terhadap total penjualan dalam perekonomian. Periklanan, pengemasan, dan kegiatan promosi yang invoatif akan menarik perhatian dan meningkatkan daya saing dari konsumen.

d. Peningkatan Keuntungan

\footnotetext{
2 Franck Cochoy, 'The American Marketing Association', Journal of Historical Research in Marketing, 6.4 (2014) <https://doi.org/10.1108/jhrm-01-2013-0003>.

${ }^{3}$ Michael J Thomas, 'Marketing Management: Analysis, Planning and Control (Book)', Journal of Business, 40 (1967).
} 
Departemen pemasaran adalah satu-satunya departemen yang memperoleh pendapatan dan keuntungan yang dihasilkan dari sebuah perusahaan. Keuntungan yang cukup mestinya diperoleh untuk menjual barang atau produk jualannya yang memenuhi persyaratan. Jika perusahaan tidak memperoleh hasil keuntungan yang lebih, maka perusahaan mereka tidak akan bertahan. Selain itu, laba sangat penting untuk pertumbuhan dan diversifikasi perusahaan untuk melanjutkan nasib dari perusahaan sendiri.

e. Pencitraan Produk yang Baik di Mata Publik Membangun citra dan perhatian produk yang baik di mata publik adalah tujuan manajemen pemasaran yang penting lainnya. Jika departemen pemasaran menyediakan produk berkualitas tinggi kepada pelanggan dengan harga yang wajar, hal itu pasti akan membentuk citra dan kepercayaan yang baik di antara perusahaan dan pelanggan sendiri.

f. Menciptakan Pelanggan Baru

Buat pelanggan baru Bisnis didirikan untuk menjual barang, produk, jasa atau layanan kepada konsumen atau pelanggan. Oleh karena itu, pelanggan adalah hal yang paling penting dan utama bahasa sederhananya adalah fondasi perusahaan. Pelanggan memberikan pendapatan pada bisnis dan menentukan apa yang akan dijual perusahaan. Dan nantinya pelanggan adalah penentu dari kelanjutan bisnis pada suatu perusahaan.

g. Menciptakan pelanggan baru

Buat pelanggan baru Ini berarti mengeksplorasi dan mengidentifikasi kebutuhan pelanggan secara lebih luas. Jika sebuah perusahaan ingin mengembangkan dan mempertahankan bisnisnya, hal tentang menciptakan pelanggan baru sangatlah penting untuk menyebarkan barang yang dijualkan, dan Anda harus menganalisis dan memahami apa yang mereka butuhkan dan inginkan.

h. Memuaskan Pelanggan

Memuaskan pelanggan Menciptakan pelanggan baru saja tentu saja tidak cukup. Perusahaan harus bisa dan mampu mengembangkan dan 
mendistribusikan produk dan layanan yang memenuhi harapan dan keinginan mereka untuk memuaskan pelanggan atau konsumen. Jika pelanggan tidak puas, perusahaan tidak akan dapat menghasilkan pendapatan lebih untuk menutupi biaya dan memperoleh pengembalian modal yang wajar atau perusahaan tidak akan mendapat keuntungan yang diharapkan.

\section{Konsep Manajemen Pemasaran}

Falsafah konsep pemasaran bertujuan memberikan kepuasan terhadap keinginan dan kebutuhan pembeli/konsumen. Seluruh kegiatan dalam perusahaan yang menganut konsep pemasaran harus diarahkan untuk memenuhi tujuan tersebut.Secara definitif dapat dikatakan bahwa: Konsep Pemasaran adalah sebuah falsafah bisnis yang menyatakan bahwa pemuasan kebutuhan konsumen merupakan syarat ekonomi dan sosial bagi kelangsungan hidup perusahaan.

Elemen Penting dalam Konsep Pemasaran:

a. Market oriented berorientasi pada keinginan Konsumen;

b. Penyusunan kegiatan pemasaran secara terpadu;

c. Pencapaian tingkat kepuasan Konsumen.

Konsep Manajemen pada hakikatnya mencakup upaya dan strategi yang ditempuhmanajemen dalam rangka untuk mencapai tingkat kepuasan konsumen.

Beberapa istilah yang sangat penting dalam konteks pemasaran yaitu:

a. Produk (barang, jasa, ide); Segala hasil kerja manusia yang dapat ditawarkan kepada manusia lainnya baik berupa barang, jasa atau ide. Konsumen akan menyukai produk yang menawarkan mutu terbaik, kinerja terbaik dan sifat terbaik sehingga perusahaan harus memfokuskan diri pada perbaikan produk yang terus menerus, menyukai produk yang mudah diperoleh dan sangat terjangkau karenanya manajemen harus berfokus pada perbaikan efisiensi produksi dan distribusi. 
b. Nilai; Perkiraan konsumen atas suatu produk untuk kepuasan mereka, apa yang dirasakan / diinginkan, perbedaan antara nilai yang dinikmati pelanggan karena memiliki serta menggunakan suatu produk dan biaya untuk memiliki produk tersebut

c. Biaya; Harga yang harus dibayar konsumen atas produk yang dikonsumsi

d. Kepuasan; Seberapa puas konsumen atas produk yang mereka konsumsi (kesesuaian antara harapan dan kenyataan), Kepuasan (customer satisfaction): tingkatan dimana kinerja yang dirasakan (perceived performance) poduk akan sesuai dengan harapan seorang pembeli atau tidak

e. Pasar; Tempat yang berisi semua pelanggan potensial yang berniat untuk transaksi terhadap suatu produk.

\section{Perencanaan Strategi Pemasaran}

Perencanaan strategi pemasaran adalah salah satu kegiatan pokok yang dilakukan oleh perusahaan tertentu untuk mempertahankan suatu kelangsungan perusahaannya, untuk supaya berkembang, dan untuk mendapatkan suatu laba. Sangat harus diperhatikan dalam mencapai suatu tujuan pemasaran tersebut, maka dari itu suatu perusahaan harus memperhatikan strategi pemasaran. Strategi pemasaran adalah suatu rangkaian, tujuan, dan sasaran, kebijakan serta suatu aturan yang memberi arah kepada usaha-usaha pemasaran dari waktu ke waktu pada masingmasing tingkatan serta lokasinya. Strategi pemasaran merupakan hal yang sangat penting bagi perusahaan dimana strategi pemasaran merupakan suatu cara mencapai tujuan yang diinginkan dari sebuah perusahaan.

Penerapan strategi pemasaran melalui beberpa langkah sebagai berikut :

a. Segmentasi pasar ( market segmentation), adalah tindakan membagi pasar menjadi kelompok pembeli berbeda dengan kebutuhan, karakteristik atau prilaku berbeda yang mungkin memerlukan produk atau bauran pemasaran terpisah.

b. Penetapan Target Pasar ( market targeting ), yaitu proses mengevaluasi daya tarik masing-masing segmen pasar dan memilih satu atau lebih 
segmen yang akan dilayani, penetapan sasaran pasar terdiri dari merancang sertategi untuk membangun hubungan yang benar dengan pelanggan yang tepat, atau sebuah perusahaan besar mungkin memutuskan untuk menawarkan ragam produk yang lengkap dalam melayani seluruh segmen pasarnnya, sebagian besar perusahaan memasuki pasar baru dengan melayani segmen tunggal, dan jika hal ini terbukti berhasil, mereka menambahkan segmen

c. Diferensiasi dan posisi pasar ( Differentiation and positioning), perusahaan harus memutuskan bagaimana mendiferensiasikan penawaran pasarnnya untuk setiap segmen sasaran dan posisi apa yang ingin ditempatinnya dalam segmen tersebut, posisi produk adalah tempat yang diduduki produk relative terhadap persaingan dalam pikiran konsumen, pemasar ingin mengembangkan posisi pasar unik bagi produk mereka. Jika sebuah produk dianggap sama persis dengan produk lainnya dipasar, konsumen tidak mempunyai alasan untuk membelinnya.

Beberapa strategi pemasaran :

a. Strategi pertama adalah melakukan promosi. Promosi adalah upaya untuk memperkenalkan sebuah produk bisnis kepada konsumen sebagai bagian dari strategi pemasaran, dari yang belum tahu menjadi tahu. Ada yang beranggapan bahawa produk yang berkualitas akan terjual dengan sendirinya. Tetapi, dalam strategi mempromosi, pemasar melaksanakan kegiatan memperkenalkan produk yang hendak ditawarkan kepada pengguna.

Dalam usaha tersebut berbagai kaedah promosi perlu dilaksanakan agar pengguna mengetahui, memahami dan seterusnya membuat keputusan untuk menggunakan produk. Tanpa kegiatan promosi, pemasaran produk yang berkualitas pun tidak menjadi aktif dan industri sukar memperoleh tahap kompetitif yang dikehendaki di pasaran.

b. Strategi kedua adalah mengembangkan produk dan sistem mencakup perubahan barang atau jasa dengan tetap menggunakan cara produksi lama. Pengembangan sistem dilaksanakan dalam suatu kerangka 
rencana induk sistem yang mengkoordinasikan proyek-proyek pengembangan sistem ke dalam rencana strategis perusahaan. ${ }^{4}$

Umumnya strategi ini dilakukan untuk memperpanjang masa edar atau siklus hidup, bilamana perusahaan mengetahui bahwa sasaran pembeli mulai bosan dan perusahaan harus mengubah barang atau jasa yang ditawarkan tersebut.

c. Strategi ketiga adalah menerapkan biaya murah. Strategi ini didasarkan pada biaya input yang rendah sehingga dapat menghasilkan barang atau jasa yang murah juga, namun bukan berarti menawarkannya dengan kualitas yang rendah.

d. Strategi keempat adalah strategi menembus pasar untuk menjangkau sasaran pembeli yang belum tercapai. Strategi ini digunakan jika perusahaan masih banyak sasaran pembeli yang belum dapat dijangkau oleh barang atau jasa yang ditawarkan, atau masih banyak sasaran pembeli yang belum menggunakan barang atau jasa perusahaan. Strategi ini sebenarnya digunakan untuk meningkatkan penjualan dengan menawarkan barang atau jasa kepada sasaran pembeli yang sama, baik yang pernah menggunakan barang atau jasa perusahaan maupun yang belum.

\section{Objek Penelitian}

Dalam kesempatan ini kami meneliti sebuah UMKM yaitu:

Nama : KPOP ONLINE SHOP @ KSHIRTTG_

Alamat : Karanganom, Kec. Durenan, Kab. Trenggalek

Bidang : Industri Tekstil, Percetakan dan Perdagangan.

A. Berikut uraian singkat objek penelitian.

K-SHIRT TG @kshirttg_adalah username yang telah dikenal untuk online shop yang aktif di Platform Instagram dan Shopee. UMKM yang bergerak di industri tekstil, percetakan, dan perdagangan barang-barang K-POP seperti kaos, jacket, sweeter, accesoris, photocard, dll yang berlokasi di Jalan R.A Kartini, Dusun Dempok RT. 016 RW. 003 Desa Karanganom,

${ }^{4}$ Rachmad Gesah and Mukti Prabowo, 'Pengembangan Sistem', 2015. 
Kecamatan Durenan, Kabupaten Trengalek, Jawa Timur, INDONESIA. Pengalaman menekuni di bidang industry tekstil dan percetakan ini sejak tahun 2019 berawal dari kegemaran owner kepada music K-POP yang akhirnya memberi ide dan motivasi memulai usaha ini. Hampir 2 tahun berjalan membuat variasi dan kualitas produk semakin meningkat. Produkproduk KPOP ONLINE SHOP @KSHIRTTG_antara lain :

- Jacket;

- Hoodie;

- Sweeter;

- Kaos;

- Topi ;

- Bucket Hat;

- Hiasan Dinding (Picture Board);

- Photocard;

- ID Card;

- Poster;

- Botol Air Minum (Tumblr);

- Sticker;

- Gantungan Kunci;

- Dll.

B. Visi \& Misi ADINDA KONVEKSI

- Visi (Vision)

Menjadi Produsen dan Distributor K-POP berskala nasional dan international.

- Misi (Mision)

1. Menyediakan produk K-POP dengan kualitas produk yang berorientasi pada peningkatan citra, estetika dan customer brand konsumen.

2. Menghasilkan produk dengan terus berinovasi serta variative.

3. Menjalin kerjasama dengan berbagai mitra, serta konsisten dalam pengembangan kualitas produk.

4. Terus memberi informasi dan komunikasi. 
5. Meningkatkan kualitas pelayanan penjualan terhadap calon pembeli dalam berbelanja online.

6. Memperluas area pemasaran hingga internasional.

7. Metodologi Penelitian

Dalam menyelesaikan penelitian yang diteliti oleh penulis kali ini, penulis menggunakan metode kualitatif. Penelitian kualitatif adalah suatu proses penelitian yang menghasilkan data deskriptif berupa kata-kata atau katakata dengan mengamati orang-orang dan tingkah laku. Peneliti tidak menggunakan angka atau rumus statistik saat mengumpulkan data dan memberikan hasil untuk penelitian. Dalam penelitian ini peneliti mencoba mendeskripsikan berbagai situasi, kondisi, atau fenomena yang ada. Format deskripsi kualitatif dirasa cocok untuk penelitian tentang isu-isu yang memerlukan penelitian mendalam, seperti penelitian tentang perilaku konsumen, pengaruh media, dan implementasi kebijakan. Dalam penelitian yang diteliti oleh peneliti kali ini, peneliti mencocokkan realitas empiris dengan teori-teori populer yang telah berlaku. Penelitian kualitatif berarti tradisi khusus dalam pengetahuan ilmu sosial, yang pada dasarnya bergantung pada observasi, manusia, bidangnya, dan pengetahuan yang berkaitan dengan bahasa dan terminologi orang-orang ini. Jenis dari penelitian yang diteliti penulis adalah deskriptif.

Penelitian ini dilaksanakan di KSHITTG BASE (@kshirttg) yang beralamat di Jalan R.A Kartini, Dusun Dempok RT. 016 RW. 003 Desa Karanganom Kecamatan Durenan, Kabupaten Trenggalek, JAWA TIMUR. Pada tanggal 15 Oktober 2020 s.d 31 Oktober 2020. Penelitian kualitatif tidak dimaksudkan untuk meringkas hasil penelitian. Hasil penelitian bersifat kontekstual dan akademis, dapat diterapkan pada waktu dan tempat tertentu dimana penelitian dilakukan. Subjek dari penelitian ini adalah KPOP ONLINE SHOP “KSHIRT TG” (@kshirttg_) sedangkan objeknya adalah menejemen pemasaran secara online.

Untuk teknik pengumpulan data, peneliti akan melakukan interview sumber atau wawancara sumber kemudian observasi langsung di tempat terjadinya penelitian dan mengumpulkan dokumen dokumen pendukung untuk 
mengumpulkan data selama penelitian. Untuk instrumen penelitian kualitatif sendiri peneliti adalah intrumen riset yang paling utama untuk melangsungkan penelitian. Peneliti akan mengkaji, meneliti, dan menganalisis data secara detail dan mendalam tentang MANAJEMEN PEMASARAN KPOP ONLINE SHOP “K-SHIRT TG” (@kshirttg_). Peneliti juga menggunakan buku pegangan untuk panduan penelitian lebih lanjut agar penelitian bisa berjalan dengan lancard dan berguna untuk mendukung validasi data yang diteliti oleh penulis. Kemudian peneliti akan menjelaskan data yang valid mengenai MANAJEMEN PEMASARAN KPOP ONLINE SHOP “K-SHIRT TG”(@kshirttg_). Kemudian catatan lapangan, Catatan lapangan adalah alat tulis yang digunakan peneliti untuk mencatat momen momen penting dan ringkasan selama melakukan Dokumentasi penilitian. Pedoman ini digunakan untuk mencatat dan mempelajari berbagai informasi yang relevan dari literatur seperti buku, arsip, jurnal, maupun dokumen di tempat kejadian penelitian. Dokumen dokumen ini akan membantu peneliti untuk menemukan data data penelitian yang dibutuhkan.

6. Hasil Dan Pembahasan

Setelah interview sumber dan observasi langsung peneliti akhirnya bisa menjelaskan hasil dan pembahasan dari penelitian kali ini. Peneliti melakukan observasi langsung di tempat K-SHIRT TG yang beralamat di Desa Karanganom, Kecamatan Durenan Kabupaten Treggalek. JAWA TIMUR. Dari Hasil interview sumber dari penelitian ini adalah dalam proses pemasaran di UMKM ini $98 \%$ menggunakan sosial platfrom atau internet. Pemilik memeliki strategi yang bagus dan baik sehingga produk banyak diminati pelanggan. Inovasi produk yang beragam di setiap minggunya membuat pelanggan tetap kembali untuk membeli produk baru. Membuat inovasi produk berdasarkan kebutuhan adalah salah satu strategi pemasaran yang bagus. Tetapi juga memperhatikan standar kualitas produk dan membuat paket ekonomis agar produk bisa bertahan.

Produk yang ditawarkan UMKM adalah produk pre-order atau sesuai pesanan, maka diperlukan desain yang bagus dan menarik untuk setiap 
produknya. Owner menggunakan beberapa aplikasi untuk membuat karya produknya lebih menarik lagi sebagai promosi. Pada awalnya owner hanya menggunakan aplikasi seperti PicsArt, Canva dan Inshot untuk mendesain produknya. Tetapi owner mulai berkembang dengan menggunakan aplikasi computer yaitu Coreldraw untuk desain yang lebih baik. Penggunaan aplikasi smartphone masih tetap digunakan.

Owner juga tetap menerapkan metode survei untuk mengatur menejemn pemasaran produk usahanya. Sehingga seriring berjalannya waktu KSHIRT TG mulai dikenal banyak khalayak dan mulai banyak pembeli dan langganannya. Karena selain produk yang dihasilkan adalah home industry yang menjual produk cukup murah namun kualitas dari produknya tetap terjamin dan tidak kalah dengan produk produk lainnya. Sehingga sangat efektif untuk dijual melalui media online.

K-SHIRT TG harus tetap mempertahankan menejemen pemasaran yang telah ia bangun untuk mempertahankan usahanya. Karena Menurut statistik tahunan Orang Indonesia di 2019 yang menggunakan pemasaran online hanya Sekitar 15,08\% dari total keseluruhan Pemasaran online. Oleh karena itu pemasaran online adalah salah satu Teknik yang efektif pada saat ini terutama di era itu Revolusi Industri 4.0.

Menurut hasil penelitian kuantitatif yang dilakukan oleh Setiawati, pemasaran online berpengaruh positif terhadap pertumbuhan laba UMKM di Jawa Tengah. Dalam penelitian ini, data yang diperoleh merupakan data utama yang diperoleh dengan mengirimkan kuesioner kepada responden secara online dan offline. Mengingat banyaknya pengguna internet di Indonesia, sistem pemasaran online ini dapat meningkatkan kesejahteraan masyarakat. Dengan memaksimalkan pemasaran online di bidang UMKM maka keuntungan penjualan akan meningkat. Adinda konveksi juga mendapatkan pelanggan tidak hanya dari sekitar kotanya saja melainkan juga diluar kota karena media online sendiri memiliki banyak sekali pengguna dari seluruh kalangan masyarakat

Sistem pemasaran online memiliki berbagai jenis manajemen, dan diyakini bahwa strategi pemasaran online dengan menggunakan Instagram sangat 
efektif. Mereka menggunakan situs web dan pasar untuk mengarahkan pembeli langsung ke media sosial mereka. Dengan cara ini, lalu lintas pengunjung Instagram mereka secara otomatis akan meningkat drastis.

Sistem promosi yang mereka gunakan adalah sistem pengiriman berita dan kupon online. Selain itu, mereka juga melakukan promosi dalam bentuk hadiah dan pengakuan. Strategi lain yang ditempuh oleh fashion adalah memperbanyak jenis dan variasi produk. Hal ini terlihat dari perkembangan toko yang semakin pesat, seiring dengan bertambahnya variasi dan koleksinya.

Selain promosi dan Endorsement, mereka juga memberikan jaminan jika terjadi kesalahan produk atau cacat produk selama pengiriman. Dengan media online seperti instagram dan website tersebut banyak sekali khalayak yang sudah mengenal K-SHIRTTG dan banyak sekali yang mengunjugi situs milik K-SHIRT TG sendiri.

Selama pandemi COVID-19 yang melanda dunia sejak awal tahun 2020 telah memberikan dampak yang cukup besar bagi perekonomian Indonesia, khususnya bagi usaha mikro, kecil dan menengah (UMKM). Seperti yang dialami K-SHIRT TG selama pandemi ini, ternyata terdapat berbagai kendala yaitu penjualan yang menurun, distribusi yang terbatas dan kesulitan bahan baku. Problematika ini membuat pemilik usaha atau pelaku UMKM dituntut untuk bisa menemukan srategi dan ide ide baru.

Selain kendala tersebut, dalam pemasarannya K-SHIRT TG yang dari awal merupakan toko online tidak mendapat banyak kepercayaan dari pelanggan sekitar karena tidak mempunyai toko nyata. Terbatasnya alat juga sangat berpengaruh terhadap pemenuhan permintaan pembeli karena harus menyelesaikan pembuatan denga mitra akan memperlambat waktu pembuatan produk. 


\section{Kesimpulan}

Dari hasil penelitian yang telah dipaparkan peneliti. Dengan demikian dapat ditarik kesimpulan bahwa pemasaran dengan media internet merupakan hal yang sangat bagus dalam pemasaran produk di era modern seperti saat ini. Namun pelaku usaha online seharusnya tidak tetap dengan online shopnya tetapi juga harus berkembang menjadi sebuah toko yang dapat menambah banyak kepercayaan dari konsumen sekitar.

Tahun 2020 menjadi tahun terberat dalam dunia wirausaha akibat pandemi Covid19 yang sudah ada sejak akhir tahun 2019 yang memaksa setiap usaha untuk memutar haluan strategi karena daya beli public yang menurun. Hal ini berdampak pada bisnis sektor UMKM karena masalah ketersediaan bahan baku dan juga peraturan pembatasan sosial. Hampir semua pelaku usaha di sekotor UMKM ini mengalami penurunan omzet penjualan yang sangat drastis, mengalami berbagai kendala pemasaran dan penjualan, juga distribusi produk. Di satu sisi para pelaku usaha mengupayakan untuk menemukan alternatif pemasaran dan penjualan, mengamankan modal dan aset, mengalihkan sementara untuk usaha lainnya, dan harus mempelajari teknologi yang dipandang efektif untuk melakukan promosi dan penjualan. Para pelaku usaha di sektor UMKM ini berupaya mempertahankan bisnis atas usahanya di tengah pandemi Covid 19 dengan tetap mengikuti aturan pemerintah dan protokol kesehatan serta keamanan dengan berbagai upaya yang diamati, diidentifikasi , membuat keputusan, dan melakukan aktivitas kembali dengan terus melakukan observasi, mengidentifikasi, membuat keputusan, dan bertindak secara terus menerus dalam satu siklus yang tidak dibatasi waktu. 


\section{DAFTAR PUSTAKA}

Cochoy, Franck, 'The American Marketing Association', Journal of Historical Research in Marketing, 6.4 (2014) <https://doi.org/10.1108/jhrm-01-20130003>

Gesah, Rachmad, Mukti Prabowo, 'Pengembangan Sistem', 2015

Kotler, Philip, 'Marketing Management: Analysis Planning Implementation and Control', Journal of Retailing, 88(3) (1994)

Thomas, Michael J, 'Marketing Management: Analysis, Planning and Control (Book)', Journal of Business, 40 (1967) 